\title{
WORK ENGAGEMENT DITINJAU DARI SELF-EFFICACY DAN WORK-STUDY PADA MAHASISWA BEKERJA DI TINGKAT AKHIR UNIVERSITAS BUANA PERJUANGAN KARAWANG
}

\author{
Cahyati Yulia Hoza ${ }^{1}$, Linda Mora ${ }^{2}$, Marhisar Simatupang ${ }^{3}$ \\ Email: Ps17.Cahyatihoza@mhs.ubpkarawang.ac.id \\ Fakultas Psikologi Universitas Buana Perjuangan Karawang
}

\begin{abstract}
The purpose of this study was to determine the effect of self-efficacy and work-study conflict on work engagement in students working at the final level of the University of Buana Perjuangan Karawang. The type of research used in this research is quantitative research methods. The sampling technique used in this research is quota sampling (Nonprobability). The population in this study was 834 respondents with a sample of 247 respondents. The data collection technique used a Likert scale. Then the data analysis was carried out using multiple regression tests on the self-efficacy variable on work engagement with the results of the sig value. $0.000<0.05$ and the work-study conflict variable on work engagement with the result of sig. 0.029<0.05. Therefore, the hypothesis in this study is Ha accepted and HO rejected. It can be concluded that there is an influence of self-efficacy and work-study conflict toward work engagement in students working at the final stage in the University of Buana Perjuangan Karawang.
\end{abstract}

Keywords: Self-efficacy, Work-study conflict and Work engagement.

\begin{abstract}
Abstrak
Tujuan dari penelitian ini adalah untuk mengetahui pengaruh self-efficacy dan workstudy conflict terhadap work engagement pada mahasiswa bekerja di tingkat akhir Universitas Buana Perjuangan Karawang. Jenis penelitian yang digunakan dalam penelitian ini adalah metode penelitian kuantitatif. Teknik pengambilan sampling yang digunakan pada penelitian ini adalah quota sampling (Nonprobability). Populasi dalam penelitian ini sebanyak 834 responden dengan sample 247 responden. Teknik pengumpulan data menggunakan skala likert. Kemudian analisis data dilakukan menggunakan uji regresi berganda pada variabel self-efficacy terhadap work engagement dengan hasil nilai sig. $0,000<0,05$ dan pada variabel work-study conflict terhadap work engagement dengan hasil nilai sig. 0,029<0,05 artinya dapat dikatakan bahwa hipotesis dalam penelitian ini yaitu $\mathrm{Ha}$ diterima dan $\mathrm{H} 0$ ditolak. artinya ada pengaruh self-efficacy dan work- study conflict terhadap work engagement pada mahasiswa bekerja di tingkat akhir Universitas Buana Perjuangan Karawang.
\end{abstract}

Kata Kunci: Self-efficacy, Work-study conflict dan Work engagement.

29 Psikologi Prima |e-ISSN : 2598-8026 | DOI : 10.34012 


\section{PENDAHULUAN}

Sumber daya manusia merupakan salah satu aset paling berharga yang dimiliki oleh suatu organisasi atau perusahaan yang paling utama, karena manusialah yang merupakan satu- satunya sumber daya yang dapat menggerakkan sumber daya lainnya. Dengan demikian, unsur sumber daya manusia merupakan faktor kunci yang harus dipertahankan suatu organisasi atau perusahaan sejalan dengan tuntutan yang senantiasa dihadapi untuk menjawab setiap tantangan yang ada. Oleh karena itu, upaya untuk mempertahankan sumber daya manusia yang berkualitas merupakan langkah utama suatu organisasi atau perusahaan.

Bentuk yang paling mendukung untuk kemajuan dan perkembangan suatu perusahaan salah satunya ialah work engagement. Work engagement merupakan sikap dan perilaku karyawan dalam bekerja dengan mengekspresikan diri secara total. Dengan demikian mahasiswa yang memiliki peran lebih dari satu harus bisa mempertimbangkan kedua peran yang sedang mahasiswajalankan. Di mana setiap perusahaan membutuhkan karyawan work engagement yang proaktif dan memiliki komitmen yang tinggi untuk bekerja, sehingga perusahaan mampu bertahan dalam menghadapi persaingan yang makin kuat (Bakker \& Demerouti, 2008). Perusahaan yang bergerak maju dalam jangka panjang harus mempertimbangkan mengenai work engagement pada karyawan. Tetapi tidak banyak perusahaan yang meperbolehkan karyawannya untuk bekerja sambil berkuliah.

Menurut Suwarso (2018), beberapa faktor utama yang mendorong mahasiswa/i untuk bekerja selama menempuh pendidikannya dijenjang perguruan tinggi adalah kendala biaya, baik biaya pendidikan kuliah maupun biaya hidup selama kuliah. Faktor lainnya adalah kemandirian, force majeur, waktu, pengalaman dan perbandingan. Mahasiswa yang bekerja harus dapat membagi waktu dan tanggung jawab terhadap komitmen dari kedua aktivitas tersebut. Hal inilah yang membuat mahasiswa menghabiskan sebagian waktu, energi serta tenaga dan pikirannya untuk bekerja. Kondisi tersebut membuat mahasiswa mengalami kesulitan dalam mengatur atau membagi waktu antara bekerja dan kuliah (Mardalena dan Muhson, 2017).

Dengan demikian pada karyawan yang memiliki engagement yang tinggi, membuat karyawan tersebut sangat termotivasi dalam bekerja serta memiliki komitmen, antusias dan bersemangat (Ari, Mujiasih \& Prihatsanti 2013). Karyawan yang memiliki engagement dapat dilihat dengan tidak merasakan pekerjaan sepenuhnya tentang deskripsi pekerjaan yang dilakukan namun karyawan mampu fokus pada tujuan dan mencoba untuk mencapai secara konsisten akan suksesnya suatu perusahaan. Sehingga karyawan akan secara aktif mencari jalan untuk dapat memperluas kemampuan yang dimiliki serta karyawan pantang menyerah walau dihadapkan dengan situasi yang menyulitkan. Seperti karyawan yang sambil kuliah, dua posisi mana yang paling harus diutamakan sehingga dapat terlihat sejauh mana self-efficacy yang dimiliki karyawantersebut.

Menurut Bakker dan Demerouti (2008) terdapat faktor-faktor yang dapat memengaruhi work engagement yaitu seperti sumber kerja (job resources) dan sumber daya pribadi (personal resources). Work engagement juga dapat dipengaruhi oleh job resources yaitu aspek-aspek fisik, sosial maupun organisasi yang berfungsi sebagai media untuk mencapai tujuan pekerjaan baik secara fisiologis maupun

30 Psikologi Prima |e-ISSN : 2598-8026 | DOI : 10.34012 
psikologis yang harus dikeluarkan serta menstimulasi pertumbuhan dan perkembangan individu. Personal resource adalah evaluasi diri positif yang terkait dengan ketahanan dan mengacu pada rasa individu dari kemampuan subjek untuk mengendalikan dan memberikan dampak yang baik pada lingkungan subjek (Ari, dkk 2013). Personal resources merupakan aspek diri dan pada umumnya dihubungkan dengan kegembiraan dan perasaan bahwa dirinya mampu memanipulasi, mengontrol dan memberikan dampak pada lingkungan sesuai dengan keinginan dan kemampuannya. Hasil penelitian yang dilakukan oleh Ardy, Astuty dan Sulistyo (dalam Hayuningtias \& Helmi, 2015) menunjukkan adanya korelasi antara self-efficacy dengan work engagement. Individu yang memiliki self-efficacy yang tinggi salah satunya dapat mempermudah tugas-tugas atau tingkat kesulitan tugas yang mereka alami.

Self-efficacy merupakan salah satu aspek pengetahuan tentang diri atau selfknowledge yang memberikan pengaruh pada kehidupan sehari-hari manusia. Selfefficacy merupakan keyakinan yang dimiliki oleh individu dalam menyelesaikan tugas atau masalah yang dihadapi dalam pekerjaannya (Lunnenburg, 2011). Selfefficacy juga berpengaruh bagi individu dalam bertindak dan membuat keputusan untuk mencapai tujuannya. Motivasi diri yang timbul dalam diri individu didorong oleh rasa percaya akan kemampuan yang dimiliki daripada sesuatu yang benar secara objektif. Engko (2008) menyatakan bahwa self-efficacy mampu memengaruhi kinerja dari seorang karyawan. Self-efficacy juga berpengaruh signifikan pada sejauh mana keterikatan kerja karyawan. Persepsi pribadi seperti ini sangat berperan dalam mengembangkan niat individu.Self-efficacy yang tinggi dalam diri seseorang mampu memberikan kemampuan untuk bertahan dalam kesulitan yang dihadapi serta mampu mengatasi persoalan atau hambatan yang mengganggudalam mencapai tujuannya.

Faktor lain yang berpengaruh bagi work engagement adalah work-study conflict. Pada penelitian terdahulu yang dilakukan oleh Kalesaran, Moningka dan Angkawijaya (2017) bahwa terdapat korelasi negatif dan signifikan antara workstudy conflict dengan work engagement. Karena makin rendah tingkat work-study conflict, maka makin tinggi tingkat work engagement dan sebaliknya, makin tinggi tingkat work-study conflict, maka makin rendah tingkat workengagement tersebut. Penelitian lainnya mengemukakan hal yang sama, pada penelitian yang dilakukan oleh Nurfitri dan Masykur (2016) bahwasanya ketika seseorang memeliki work-study conflict yang tinggi maka tingkat work engagement yang individu miliki akan makin rendah bahkan tidak ada tetapi ketika seseorang yang memiliki work-study confilict yang rendah maka work engagement tersebut akan makin tinggi dan signifikan.

Work-study conflict merupakan bentuk konflik interperan, di mana mahasiswa yang memilih bekerja harus memenuhi dua tuntutan peran yaitu sebagai mahasiswa dan pegawai (Nurfittri \& Masykur 2016). Work-study conflict didefinisikan sebagai pengalaman ketika tuntutan dan tanggung jawab dalam pekerjaan mengganggu kemampuan seseorang dalam tuntutan dan tanggung jawab dalam pendidikan (Owen, Kavanagh \& Dollard, 2017). Work-study conflict dialami oleh seseorang di mana mereka harus memenuhi dua tuntutan peran sebagai pelajar dan pekerja. Dampak konflik ini ditunjukkan dengan adanya kelelahan fisik, kurang waktu untuk mengurus kuliah dan sulit konsentrasi. Tidak sedikit mahasiswa yang bekerja lebih 
banyak merasa lelah dibandingkan merasakan manfaat dari kedua peran tersebut (Vickers, 2003).

Hubungannya dengan mahasiswa yang bekerja yaitu mereka merasa kurang memiliki kebermaknaan tugas dalam bekerja, mereka merasa pekerjaan yang dilakukan cenderung monoton sehingga mereka menjadi kurang antusias dalam bekerja. Ditambah dengan adanya pandemi menyebabkan beban dan target pekerjaan mereka terlalu banyak, sehingga mengakibatkan keterpaksaan untuk menambah jam kerja, hal ini mengakibatkan rasa bangga terhadap pekerjaan mereka menjadi turun dan kurangnya semangat yang tinggi ketika bekerja. Tak hanya itu terkadang mahasiswa bekerja sering melakukan kesalahan yang berulang seperti telat masuk kerja, menurut mereka hal tersebut terkadang dianggap sepele tetapi pada kenyataannya hal sepele tersebut akan berdampak besar bagi perusahaan apabila terjadi secara terus menerus. Adanya kelelahan secara fisik dan psikis, maka mereka sering melakukan pekerjaan dengan sesuka hatinyatanpa berpedoman pada SOP yang telah ditentukan, hal ini berakibat pada hasil pekerjaannya baik secara kualitas maupun keselamatan kerja menjadi buruk. Sebagian mahasiswa di tingkat akhir ini bahkan ada yang lebih memilih untuk resign dan memfokuskan diri pada penyelesaian tugas akhirdengan harapan mereka akan mendapatkan pekerjaan yang lebih baik setelah mereka menjadi sarjana. Ketika hal-hal di atas kurang memperoleh perhatian dari diri individu khususnya daripimpinan atau perusahaan maka akan menimbulkan dampak jangka panjang bagi perusahaan (Simatupang, 2020).

\section{LANDASAN TEORI}

\section{Work engagement}

Keterikatan kerja atau work engagement menurut Khan (Dalam Ari., Mujiasih \& Prihatsanti 2013), diartikan sebagai karyawan yang bekerja dengan perhatian dan usaha yang besardan mengekspresikan diri secara fisik, kognitif dan emosional terhadap peran pekerjaannya tersebut. Karyawan dengan keterikatan kerja yang tinggi dengan kuat memihak pada jenis pekerjaan yang dilakukan dan benar-benar peduli dengan jenis pekerjaan itu. Secara ringkas Schaufali dan Bakker (dalam Sahir, dkk, 2020) menjelaskan mengenai aspek-aspek yang terdapat dalam work engagement, yaitu: Vigor (Semangat), Dedication (Dedikasi) dan Absorption (Penghayatan). Faktor yang memengaruhi keterikatan kerja Menurut Schaufeli dan Bakker (dalam Sahir dkk, 2020) antara lain: Job Demands (Tuntutan Kerja), Job Resources (Sumber Daya Pekerjaan) dan Personal Resources (Sumber Daya Pribadi).

\section{Self-efficacy}

Bandura (dalam Feist, 2013) mendefinisikan bahwa self-efficacy merupakan keyakinan seseorang dalam kemampuannya untuk melakukan suatu bentuk kontrol terhadap tugas atau tindakan yang diperlukan untuk mencapai hasil tertentu. Bandura beranggapan bahwa keyakinan atau efikasi seseorang adalah suatu landasan dari agen manusia. Menurut Bandura (dalam Ghufron \& Risnawita, 2014) selfefficacy individu akan berbeda antara satu individu dengan yang lainnya berdasakan 
tiga dimensi berikut yaitu: Tingkat (Level), Kekuatan (Strength) dan Generalisasi (Generality).

\section{Work-study conflict}

Markel dan Frone (dalam Oktavia \& Nugraha, 2013) work-study conflict merupakan keadaan di mana tuntutan dan tanggung jawab individu terhadap perannya dalam pekerjaan menghambat individu untuk memenuhi tuntutan dan tanggung jawab terhadap perannya dalam pendidikan. Markel dan Frone (dalam Oktavia dan Nugraha, 2013) menggunakan dasar dari work-family conflict di mana aspek work-family conflict digunakan sebagai landasan dan kemudian dikembangkan sebagai aspek work-study conflict. Disebutkan bahwa terdapat 2 aspek yaitu: TimeBased Conflict dan Strain Based Conflict.

\section{METODE PENELITIAN}

Dalam penelitian ini digunakan metode penelitian jenis kuantotatif dengan teknik pengambilan sample yaitu quota sampling (Nonprobability). Populasi dalam penelitian ini sebanyak 834 responden dengan sample 247 responden mahasiswa bekerja di tingkat akhir Universitas Buana Perjuangan Karawang. Teknik pengumpulan data atau alaat ukur penelitian menggunakan skala likert.Menurut Azwar (2018) skala likert merupakan skala yang disusun untukmengungkapkan sikap pro dan kontra, positif dan negatif. Setuju dan tidak setuju terhadap suatu objek sosial. Skala likert disusun dalam format checklist dan terdapat lima alternatif jawaban, yakni Sangat Sesuai (SS), Sesuai (S), Netral (N), Tidak Sesuai (TS), dan Sangat Tidak Sesuai (STS). Setiap pernyataan memiliki lima pilihan sikap yang akan dipilih salah satunya, sehingga pernyataan ini berisi pengukuran skala mengenai objek sikap yang dipilih atau dirasakan oleh responden.

\section{HASIL DAN PEMBAHASAN}

\section{Tabel 1. Uji Normalitas}

\begin{tabular}{|c|c|c|c|c|c|c|}
\hline & \multirow[b]{2}{*}{ Statistic } & \multicolumn{2}{|c|}{$\begin{array}{l}\text { Kolmogorov- } \\
\text { Smirnov }^{\mathrm{a}}\end{array}$} & \multicolumn{3}{|c|}{$\begin{array}{l}\text { Shapiro- } \\
\text { Wilk }\end{array}$} \\
\hline & & df & Sig. & Statistic & $\begin{array}{l}d \\
f\end{array}$ & Sig. \\
\hline Work Engagement & ,041 & 247 & ,200* & ,995 & 247 & 655 \\
\hline Self-Efficacy & ,047 & 247 & ,200* & ,992 & 247 & ,228 \\
\hline Work-Study Conflict & ,047 & 247 & ,200* & ,995 & 247 & ,527 \\
\hline
\end{tabular}

Berdasarkan tabel di atas hasil uji normalitas yang telah dilakukan pada ketiga variabelmenunjukkan taraf signifkansi self-efficacy, work-study conplict dan work engagement sebesar $0.200>0.05$ sehingga dapat disimpulkan bahwa variabel self-efficacy, work-study conplict dan work engagement berdistribusi normal.

\section{Tabel 2. Uji Linearitas X1-Y}




\begin{tabular}{|c|c|c|c|c|c|c|c|}
\hline & & & $\begin{array}{l}\text { Sum of } \\
\text { Squares }\end{array}$ & $\mathrm{df}$ & $\begin{array}{l}\text { Mean } \\
\text { Square }\end{array}$ & $\mathrm{F}$ & Sig. \\
\hline \multirow{5}{*}{$\begin{array}{l}\text { Work } \\
\text { Engagement } \\
\text { *Self- } \\
\text { Efficacy }\end{array}$} & \multirow{3}{*}{$\begin{array}{l}\text { Between } \\
\text { Groups }\end{array}$} & (Combined) & 198903,308 & 62 & 3208,118 & 2,319 &, 000 \\
\hline & & Linearity & 62372,050 & 1 & 62372,050 & 45,094 & 000 \\
\hline & & $\begin{array}{l}\text { Deviation from } \\
\text { Linearity }\end{array}$ & 136531,258 & 61 & 2238,217 & 1,618 & ,008 \\
\hline & \multicolumn{2}{|c|}{ Within Groups } & 254500,125 & 184 & 1383,153 & & \\
\hline & \multicolumn{2}{|l|}{ Total } & 453403,433 & 246 & & & \\
\hline
\end{tabular}

Tabel 3. Uji Linearitas X2-Y

\begin{tabular}{|c|c|c|c|c|c|c|c|}
\hline & & & $\begin{array}{l}\text { Sum of } \\
\text { Squares }\end{array}$ & df & $\begin{array}{r}\text { Mean } \\
\text { Square }\end{array}$ & $\mathrm{F}$ & Sig. \\
\hline \multirow{5}{*}{$\begin{array}{l}\text { Work } \\
\text { Engagement } * \\
\text { Work-Study } \\
\text { Conflict }\end{array}$} & \multirow{3}{*}{$\begin{array}{l}\text { Between } \\
\text { Groups }\end{array}$} & (Combined) & 205686,390 & 61 & 3371,908 & 2,518 &, 000 \\
\hline & & Linearity & 43221,804 & 1 & 43221,804 & 32,279 & ,000 \\
\hline & & $\begin{array}{l}\text { Deviation from } \\
\text { Linearity }\end{array}$ & 162464,586 & 60 & 2707,743 & 2,022 & ,000 \\
\hline & \multicolumn{2}{|c|}{ Within Groups } & 247717,043 & 185 & 1339,011 & & \\
\hline & \multicolumn{2}{|l|}{ Total } & 453403,433 & 246 & & & \\
\hline
\end{tabular}

Berdasarkan uji linearitas yang telah di lakukan dari variabel self-efficacy terhadap work engagement diperoleh Sig. Linearity sebesar 0,000 < 0,05. Dan pada variabel work-study conflict terhadap work engagement diperoleh Sig. Linearity sebesar $0,000<0,05$ yang berarti terdapat hubungan yang linear di antara ke tiga variabel tersebut.

\section{Tabel 4. Uji Regresi Linear Berganda}

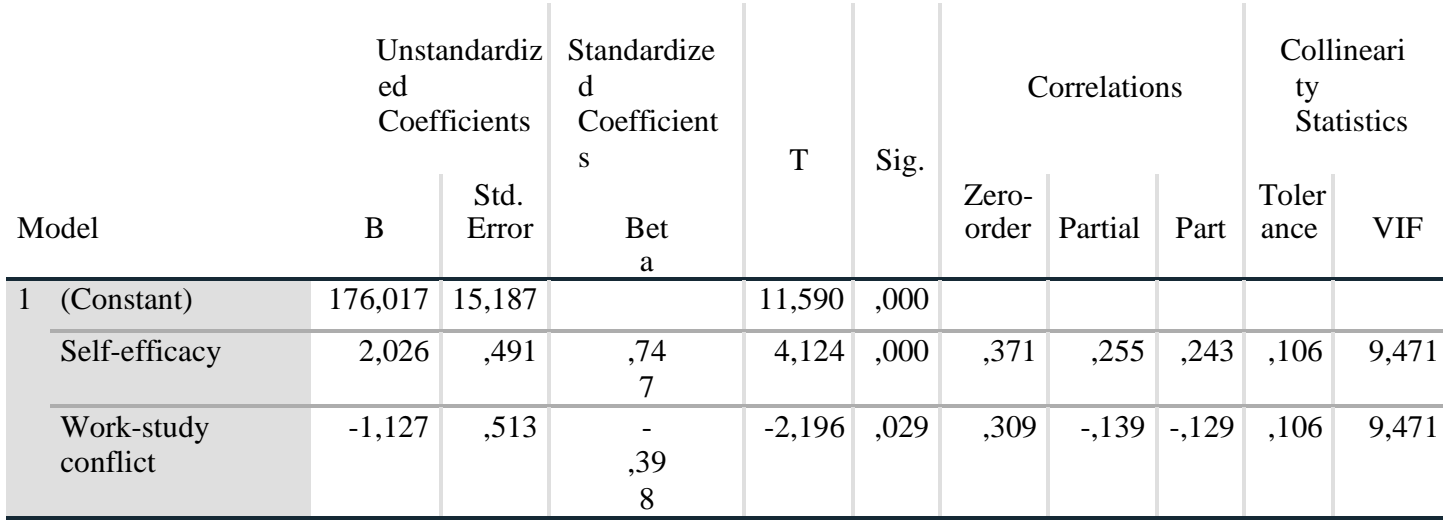

a. Dependent Variable: Work Engagement

Tabel di atas menunjukkan nilai signifikan untuk hasil uji regresi linear Berganda pada variabel (X1) adalah $0,000<0,05$ dan pada variabel (X2) adalah $0,029<0,05$ sehingga dikatakan bahwa hipotesis dalam penelitian ini yaitu $\mathrm{Ha}$ diterima dan $\mathrm{H} 0$ ditolak. Artinya ada pengaruh self-efficacy dan work-study conflict terhadap work engagemnt pada mahasiswa bekerja di tingkat akhirUniversitas Buana Perjuangan Karawang. 


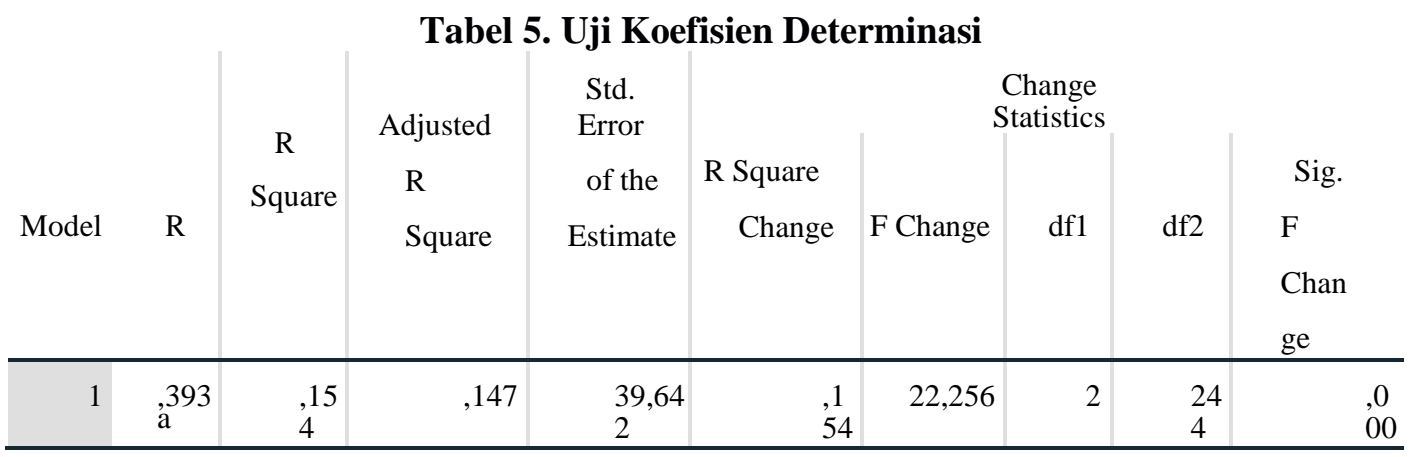

a. Predictors: (Constant), Self-efficacy, Work-study conflict

Berdasarkan tabel di atas dapat diketahui nilai R Square adalah 0,154. Jadi kemampuan dari variabel self efficacy dan work-study conflict untuk menjelaskan work engagement secara simultan yaitu 15,4\% sedangkan sisanya sebesar 84,6\% dipengaruhi oleh faktor lain yang tidak diteliti.

Tabel 6. Uji Kategorisasi Work Engagement

\begin{tabular}{llr|r|r|r} 
& & Frequency & Percent & Valid Percent & Cumulative Percent \\
\hline Valid & RENDAH & 6 & 2,4 & 2,4 & 2,4 \\
\cline { 2 - 6 } & SEDANG & 100 & 40,5 & 40,5 & 42,9 \\
\cline { 2 - 6 } & TINGGI & 141 & 57,1 & 57,1 & 100,0 \\
\cline { 2 - 6 } & Total & 247 & 100,0 & 100,0 & \\
\hline
\end{tabular}

Berdasarkan data di atas menunjukkan bahwa subjek yang memiliki selfefficacy dalam kategori rendah berjumlah 11 orang dengan persentase sebanyak $4,5 \%$, kategori sedang sebanyak 47,4\% atau 117 orang, dan kategori tinggi sebanyak 48,2\% atau 119 orang. Dapat disimpulkan bahwa frekuensi paling tinggi yang dimiliki oleh mahasiswa bekerja di tingkat akhir Universitas Buana Perjuangan Karawang pada variabel self-efficacy adalah kategori self-efficacy yang tinggi yaitu sebanyak 119 orang dengan persentase $48,2 \%$.

Tabel 7. Uji Kategorisasi Self-Efficacy

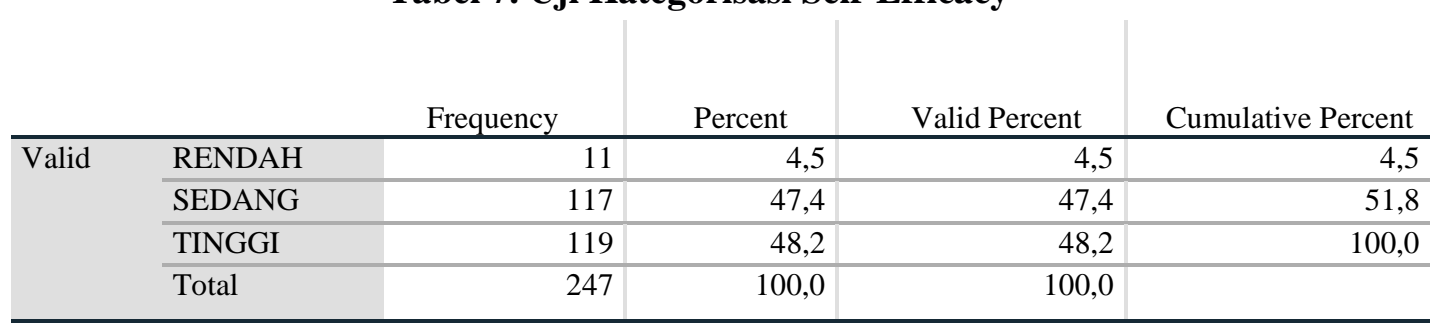

Berdasarkan data di atas menunjukkan bahwa subjek yang memiliki workstudy conflict dalam kategori rendah berjumlah 43 orang dengan persentase sebanyak $17,5 \%$, kategori sedang sebanyak $66,8 \%$ atau 165 orang, dan kategori tinggi sebanyak $15,8 \%$ atau 39 orang. Dapat disimpulkan bahwa frekuensi paling tinggi 
yang dimiliki oleh mahasiswa bekerja di tingkat akhirUniversitas Buana Perjuangan Karawang pada variabel work-study conflict adalah kategori work-study conflict yang sedang yaitu sebanyak 165 orang dengan persentase $66,8 \%$.

Tabel 8. Uji Kategorisasi Work-Study Conflict

\begin{tabular}{ll|r|r|r|r} 
& \multicolumn{2}{c|}{ Frequency } & Percent & Valid Percent & \multicolumn{2}{c}{$\begin{array}{c}\text { Cumulative } \\
\text { Percent }\end{array}$} \\
\hline Valid & RENDAH & 43 & 17,4 & 17,4 & 17,4 \\
\cline { 2 - 6 } & SEDANG & 165 & 66,8 & 66,8 & 84,2 \\
\cline { 2 - 6 } & TINGGI & 39 & 15,8 & 15,8 & 100,0 \\
\cline { 2 - 6 } & Total & 247 & 100,0 & 100,0 & \\
\hline
\end{tabular}

Berdasarkan data di atas menunjukkan bahwa subjek yang memiliki work engagement dalam kategori rendah berjumlah 6 orang dengan persentase sebanyak $2,4 \%$, kategori sedang sebanyak 40,5\% atau 100 orang, dan kategori tinggi sebanyak $57,1 \%$ atau 141 orang. Dapat disimpulkan bahwa frekuensi paling tinggi yang dimiliki oleh mahasiswa bekerja di tingkat akhir Universitas Buana Perjuangan Karawang pada variabel work engagement adalah kategori work engagement yang tinggi yaitu sebanyak 141 orang dengan persentase 57,1\%.

\section{KESIMPULAN}

Setelah seluruh data terkumpul kemudian dilakukan pengujian untuk analisis data pada setiap skala. Dari hasil analisis data rumusan masalah didapatkan bahwa terdapat pengaruh antara self-efficacy dan work-study conflict terhadap work engagement pada mahasiswa bekrja di tingkat akhir Universitas Buana Perjuangan Karawang, dibuktikan dengan hasil perhitungan nilai sig. 0,000 $(\mathrm{P}<0,05)$. Maka dapat disimpulkan bahwa $\mathrm{H}_{\mathrm{a} 3}$ diterima. Dalam hal ini sebagian besar para mahasiswa bekerja di tingkat akhir universitas buana perjuangan karawang memiliki work engagemnt yang tinggi. Menurut Nurfitria dan Masykur (2016), hal tersebut menunjukkan bahwa saat penelitian berlangsung, wayoritas subjek penelitian memiliki work-study conflict yang rendahatau sedang sehingga pegawai atau pekerja yang memiliki work engagement akan merasa terdorong untuk maju dan berkembang. Pegawai atau pekerja juga secara antusias memiliki keinginan lebih untuk terlibat dalam pekerjaannya guna pencapaian tujuan organisasi. Hal tersebut sesuai dengan ketiga dimensi yang diungkapkan oleh Schaufali dan Bakker (dalam Sahir, dkk, 2020), mengenai work engagement, yaitu vigor, dedication dan absorpstion.

Pegawai atau pekerja yang memiliki work engagement akan produktif dalam bekerja. Sesuai dengan penelitian (Imawati \& Amalia, 2011), bahwa work engagement memberikan pengaruh positif pada kinerja karyawan. Didukung pada penelitian Nugraha \& Octavia (2013), yang menunjukkan rendahnya work study conflict dapat memengaruhi adversity quotient pada mahasiswa yang bekerja. Mahasiswa yang bekerja memiliki kemampuan dalam menghadapi kesulitan dalam menjalankan aktivitas kerja dan kuliahnya. Penelitian yang di lakukan oleh Kalerasan, Moningka dan Angkawijaya (2017), memberikan hasil bahwa terdapat

36 Psikologi Prima |e-ISSN : 2598-8026 | DOI : 10.34012 
pengaruh pada self-efficacy dan work-study conflict terhadap work engagement, hal tersebut menjelaskan bahwa seseorang merasakan konflik peran, tetapi pada waktu yang bersamaan mereka meyakini bahwa mereka mampu menghadapi konflik tersebut.

\section{REFERENSI}

Adebayo, D. O. (2012). Workload, social support, and work-school conflict among Nigerian nontraditional students. Journal of Career Development, 33 (2), 125- 141.

Ari, D., Mujiasih,E., \& Prihatsanti,U. (2013). Hubungan psychological capital dengan work engagement pada karyawan PT.Bank Mega Regional Semarang. Jurnal Psikologi Undip, 12(2), 1-13.

Arshanti, T.A. (2012). Hubungan antara penetapan tujuan, self-efficacy dan kinerja. JurnalPsikologi, 16(2), 97-110.

Azwar, S. (2019). Reliabilitas dan validitas. Yogyakarta: Pustaka Pelajar.

Azwar, S (2019). Metode penelitian psikologi edisi II. Yogyakarta: Pustaka Pelajar. Azwar,S. (2020). Penyusunan skala psikologi. Yogyakarta: Pustaka Pelajar.

Bakker, A.B., \& Demerouti, E. (2008). The job demands-resources model: State of the art. Journalof Psychology, 22, 309-328.

Engko. (2008). Pengaruh kepuasan kerja terhadap kinerja individual dengan selfesteem dan self-efficacy sebagai variabel intervening. Jurnal Bisnis dan Akuntansi, 10(1), 1-12.

Feist,J. (2013). Teori kepribadian buku 2 edisi ke 7. Jakarta: Salemba Humanika.

Gareis, K. C., Barnett, R. C., Ertel, K. A., \& Berkman, L. F. (2010, August). Workfamily enrichment and conflict: Additive effects, buffering, or balance? Journal of Marriage and Family, 71, 696-707.

Ghufron, M.N., \& Risnawita,R., (2014). Teori-teori psikologi. Jogjakarta: Ar-Ruzz Media.

Handayani, W. (2014). Dampak komitmen organisasi, self-efficacy terhadap konflik peran dan keterikatan kerja Pt. Hm Sampoerna Tbk. Di Surabaya. Jurnal Psikologi. 8(2), 70-78.

Hayuningtyas, D.R. \& Helmi, A.F. (2015). Peran kepemimpinan otentik terhadap work engagement dosen dengan efikasi diri sebagai mediator. Gadjah Mada Journal of Psychology, 1, 167-179

Jelpa,P (2019). Penelitian kuantitatif untuk psikologi. Yogyakarta: Pustaka Pelajar

Kalerasan, T., Mingingka, C., \& Angkawijaya, Y. F. (2017). The effect of conflict self-efficacy on work-study conflict in working college students. International Conference on Psychology \& Multiculturalism. 112-11 
Laughman, C., Boyd, E. M., \& Rusbasan D. (2016). Burnout as a mediator between work-school conflict and work outcomes. Journal of Career Development, $1-13$.

Lunnenburg. (2011). Self-efficacy in the workplace: implications for motivation and performance.

Journal of Management, Business, and Administration, 14(1), 1-6.

Mardalena, E., \& Muhson, A. (2017). Mahasiswa bekerja dan dampaknya pada aktivitas belajar dan prestasi akademik. Jurnal Economia,13(02), 203-209.

Menristekdikti. (2021, januari 05). Kementrian riset, teknologi, dan pendidikan tinggi republik indonesia. retrieved from perguruan tinggi: https://ristekdikti.go.id/perguruan-tinggi

Mujiasih (2011). Meningkatkan work engagement melalui gaya kepemimpinan transformasional dan budaya organisasi. Skripsi. Semarang: Fakultas Psikologi Universitas Dipenogoro.

Nurfitria, Y., \& Masykur, A. M. (2016). Hubungan antara work-study conflict dengan work engagement pada pegawai starbucks semarang. Jurnal Empati, 5(4), 765-769.

Octavia, E., \& Nugraha, S. P. (2013). Hubungan antara adversity quotient dan workstudy conflict pada mahasiswa yang bekerja. Jurnal Psikologi Integratif, 1(1), 44-51.

Owen, M. S., Kavanagh, P. S., \& Dollard, M. F. (2017). An integrated model of work-study conflict and work-study facilitation. Journal of Career Development, 45(5).

Park, Y. \& Sprung, J. M. (2013). Work-school conflict and health outcomes: benefical resources for working college students. Journal of Occupational Helath Psychology, 18(4), 384- 394.

PUSDATIN. (2021, februari 9). Data mahasiswa bekerja Universitas Buana Perjuangan Karawang. (H. Mustika, Interviewer)

Sahir, H. S., Fadhli, M., Hasibuan, A. S. A., Chamida, D., Sherly, S., Revida, E., Simamata, J., \& Purba,S. (2020). Keterampilan manajerian efektif. Medan:Yayasan Kita Menulis.

Schaufeli, W. B., dan Bakker, A. B (2004). Job demands, job resources, and their relationship withburnout and engagement: A multi-sample study. Journal of Organizational Behavior, 25, 293-315.

Schaufeli, W.B., Taris, T. W., \& Van Rhenen, W. (2008). Workaholism, burnout and work engagement: Three of A kind or three different kinds of employee wellbeing? AppliedPsychology: An International Review, 57(2),173-203.

Simatupang, M. (2020). Budaya organisasi sebagai variabel predictor terhadap organizational citizenship behavior pada karyawan koperasi, Psychopedia Jurnal Psikologi Universitas Buana Perjuangan Karawang, 5(1), 8-19.

Sugiyono (2018). Metode penelitian kuantitatif. Bandung: Alfabeta

38 Psikologi Prima |e-ISSN : 2598-8026 | DOI : 10.34012 
Suwarso. (2018). Dampak kuliah sambil bekerja terhadap indeks prestasi mahasiswa perguruan tinggi negeri dan swasta di Kabupaten Jember tahun 2017. Jurnal Relasi, 14(02), 15-27.

Vickers, M. (2003). Student workers in high school and beyond: the effect of parttime employment on participation in education, training and work. Australia: Australian Council for Education Research.

Yahya, G. M. \& Widjaja, S. U. M. (2019). Analisis prestasi akademik pada mahasiswa yang bekerja parti-time di jurusan ekonomi pembanngunan fakultas ekonomi universitas negeri malang angkatan 2014. Jurnal Pendidikan Ekonomi, 12(1), 46-52 